
socioeconomia de comunidades rurais do município de Tefé, Amazonas. Oikos: Família e Sociedade em Debate, v. 31, n. 2, p. 283-312, 2020.

\title{
OS BENEFÍCIOS SOCIAIS E A SOCIOECONOMIA DE COMUNIDADES RURAIS DO MUNICÍPIO DE TEFÉ, AMAZONAS
}

\section{THE SOCIAL BENEFITS AND SOCIOECONOMY OF RURAL COMMUNITIES OF THE MUNICIPALITY OF TEFÉ, AMAZONAS}

\section{LOS BENEFICIOS SOCIALES Y LA SOCIOECONOMÍA DE LAS COMUNIDADES RURALES EN EL MUNICIPIO DE TEFÉ, AMAZONAS}

Danglares de Sousa Costa ${ }^{1}$ Alex Almeida Coelho ${ }^{2}$

\section{Resumo}

O presente artigo faz uma descrição dos impactos da presença de benefícios sociais na socioeconomia de comunidades rurais de Tefé, estado do Amazonas. Descrevemos o perfil socioeconômico das famílias, traçando um retrato de rendimentos, atividades produtivas e consumo. As comunidades são: Agrovila, Maranata, São Francisco, Agrovila da Emade, Boa Vontade e Bom Jesus. A amostra é composta de 61 domicílios, e a análise tem caráter quanti-qualitativo. Utilizou-se a estatística descritiva para a elaboração e geração de resultados sobre os rendimentos e despesas, construindo assim parte da análise das realidades sociais e econômicas das comunidades. Já a qualitativa foi realizada por meio de entrevistas abertas. Conclui-se que os benefícios sociais contribuem de forma significativa para as famílias. O Bolsa Família e as aposentadorias rurais são empregados na compra de vestuário, material escolar e alimentação. As aposentadorias também são utilizadas para compra de remédios, realização de exames, viagens e aquisição de bens de patrimônio doméstico. Possuir um cartão de benefício ou uma aposentadoria rural é garantia de crédito no mercado, pois são rendimentos mensais regulares, garantem poder de compra aos beneficiários. Portanto, de forma direta, os benefícios sociais são elementos que possibilitam novos cenários na economia dos domicílios das comunidades rurais da estrada da Agrovila e Emade, no município de Tefé.
\end{abstract}

Palavras-chave: Comunidades rurais. Renda e despesas. Benefícios. Tefé-AM.

\section{Abstract}

This article describes the impacts of the presence of social benefits on the socioeconomics of rural communities in Tefé, state of Amazonas. We describe the socioeconomic profile of the families, drawing a picture of income, productive activities and consumption. The communities are: Agrovila, Maranata, São Francisco, Agrovila da Emade, Boa Vontade and Bom Jesus. The sample is 61 households. Social benefits contribute significantly to families. Bolsa Família and rural pensions are used to purchase clothing, school supplies and food. Retirements are still used for the purchase of medicines, exams, travel and the acquisition of household goods. Owning a benefit card or a rural pension are credit guarantees in the market, they are regular monthly income, they guarantee purchasing power to the beneficiaries. Therefore, directly, social benefits are elements that enable new scenarios in the economy of households in the rural communities of the road from Agrovila and Emade, in the municipality of Tefé.

Keywords: Rural communities; income and expenses; benefits; Tefé/AM.

\footnotetext{
${ }^{1}$ Universidade do Estado do Amazonas/Centro de Estudos Superiores de Tefé/CEST/UEA. Aluno do Curso de Licenciatura em Geografia, Tefé, Amazonas, Brasil. Orcid: https://orcid.org/0000-0003-3966-0877 e-mail: danglaresdesousa@gmail.com.

${ }^{2}$ Mestre em geografia pela Universidade Federal do Amazonas/UFAM. Aluno de Doutorado no Programa de PósGraduação Mestrado e Doutorado em Geografia da Universidade Federal de Rondônia - PPGG/UNIR. Membro do Grupo Pesquisa Geografia, Natureza e Territorialidades Humanas - GENTEH, Porto Velho, Rondônia, Brasil. Orcid: https://orcid.org/0000-0003-3966-0877 e-mail: alexfonteboa@gmail.com.
} 


\section{Resumen}

Este artículo describe los impactos de la presencia de beneficios sociales en la socioeconomía de las comunidades rurales en Tefé, estado de Amazonas. Describimos el perfil socioeconómico de las familias, dibujando un cuadro de ingresos, actividades productivas y consumo. Las comunidades son: Agrovila, Maranata, São Francisco, Agrovila da Emade, Boa Vontade y Bom Jesus. La muestra consta de 61 hogares, y el análisis tiene un carácter cuantitativo y cualitativo. Se utilizaron estadísticas descriptivas para preparar y generar resultados sobre ingresos y gastos, construyendo así parte del análisis de las realidades sociales y económicas de las comunidades. La encuesta cualitativa se realizó a través de entrevistas abiertas. Se concluye que los beneficios sociales contribuyen significativamente a las familias. La Bolsa Familia y las pensiones rurales se utilizan para comprar ropa, útiles escolares y alimentos. Las jubilaciones también se utilizan para la compra de medicamentos, exámenes, viajes y la compra de artículos para el hogar. Tener una tarjeta de beneficios o una pensión rural es una garantía de crédito en el mercado, ya que son ingresos mensuales regulares, lo que garantiza el poder adquisitivo de los beneficiarios. Por lo tanto, directamente, los beneficios sociales son elementos que permiten nuevos escenarios en la economía de los hogares de las comunidades rurales en el camino a Agrovila y Emade, en el municipio de Tefé.

Palabras clave: Comunidades rurales. Ingresos y gastos. Beneficios Tefé-AM.

\section{INTRODUÇÃO}

Este estudo analisa os impactos de benefícios sociais para a socioeconomia de grupos familiares localizados ao longo das estradas da Emade e Agrovila, no município de Tefé, estado do Amazonas. As famílias que fazem parte deste estudo são em sua grande maioria populações ligadas à terra, que produzem boa parte dos recursos que necessitam para seu autoconsumo3 e mantêm também ligações com o mercado para aquisição de produtos que complementam a manutenção do grupo familiar.

Tradicionalmente, a socioeconomia das populações da região do médio Solimões pode ser caracterizada como uma economia de orientação camponesa, que tem como característica principal sua organização produtiva dentro do próprio grupo doméstico, formado por unidades familiares que são ao mesmo tempo de produção e de consumo (LIMA, 2006).

A produção, portanto, é determinada pelas necessidades de consumo da família. Nesse sentido, o valor do trabalho e dos bens de consumo variam, em virtude de se ter ou não atingido as necessidades do grupo; assim, a produtividade do trabalho é avaliada com base não nos preços de mercado, mas no esforço despendido para se atingir a subsistência e consequentemente, tão logo as necessidades básicas sejam atendidas, há tendência de abrir mão desse esforço (ABRAMOVAY, 1998).

Grande parte das populações tradicionais do médio Solimões tem suas atividades voltadas para a satisfação das necessidades do grupo familiar. A composição da renda domiciliar é proveniente da somatória do conjunto de rendimentos das atividades produtivas e de outras, e é direcionada para a satisfação das necessidades de consumo. Esses modos de

\footnotetext{
${ }^{3}$ Lima (2006) argumenta que autoconsumo é a parte da produção gerada pelo grupo familiar destinada a alimentar os indivíduos que o compõem.
} 
obtenção de renda produzem efeitos distintos sobre a estrutura das relações domésticas nas localidades amazônicas, especialmente sobre as relações de produção e consumo dos domicílios.

Os estudos sobre a organização social e econômica desses grupos familiares podem ser um mecanismo eficaz para a construção de indicadores socioeconômicos que permitem conhecer os processos de produção e. consumo, o cenário socioeconômico e as relações econômicas dos grupos domiciliares, além de permitir a construção de uma análise sobre os impactos de benefícios sociais para os grupos familiares.

Atualmente, os benefícios sociais estão muito mais presentes como fontes de ingressos regulares (Peralta e Lima, 2013; Lima e Peralta, 2016; Coelho e Peralta, 2016) e com impacto significativo para a composição da renda, novos padrões de organização e maior interação com centros urbanos. Dessa forma, procurou-se entender como estão organizados os domicílios em relação às atividades praticadas para garantir a subsistência, a organização das relações econômicas, as principais fontes de ingressos monetários dos grupos e as principais interações com o mercado.

Assim, o estudo objetivou traçar um panorama do impacto dos benefícios sociais para populações rurais de Tefé-AM. Para isso, descrevemos o perfil socioeconômico das famílias das estradas da Agrovila e Emade. Traçamos um retrato dos rendimentos, atividades produtivas, consumo das comunidades, e descrevemos os impactos dos benefícios sociais para as famílias entrevistadas.

O artigo é composto por três tópicos de análise. O primeiro, com uma revisão e análise bibliográfica sobre populações rurais da Amazônia, sua orientação produtiva e o papel dos benefícios sociais na sua socioeconomia. O segundo, sobre o perfil socioeconômico das comunidades das estradas da Agrovila e Emade, com descrição de principais fontes de renda, despesas e bens de patrimônio. Por fim, o terceiro tópico, descrevendo os impactos dos benefícios sociais na socioeconomia das famílias entrevistadas, com destaque para as percepções dos entrevistados sobre a importância e o papel dos benefícios sociais para suas famílias.

\section{METODOLOGIA}

O estudo foi realizado através de levantamento e análise de dados quantitativos e qualitativos. Para o primeiro utilizamos a estatística descritiva, para a elaboração e geração de resultados sobre os rendimentos e despesas, construindo, assim, parte da análise das realidades sociais e econômicas das comunidades. 
A primeira etapa deste estudo correspondeu à aplicação de um questionário semiestruturado com as famílias. Esses dados compõem o conjunto de informação de atividades produtivas, rendimentos e despesas, e apoiaram as descrições do perfil socioeconômico dos grupos domésticos, construindo, assim, parte da análise das realidades sociais e econômicas das comunidades. O segundo conjunto de informações que compõem este estudo são dados qualitativos, coletados por meio de roteiro de entrevistas, levantados após a análise dos dados socioeconômicos e tratando especialmente do papel dos benefícios sociais para as famílias rurais.

A análise dos dados tem caráter quantitativo e qualitativo. Utilizou-se a estatística descritiva para a elaboração e geração de resultados sobre os rendimentos e despesas. A característica principal que influenciou na escolha do uso de método de estatística descritiva na primeira parte do estudo deu-se pela possibilidade de tratar questões para uma população geralmente maior, por meio da análise de uma amostra de casos. "A análise estatística se refere ao uso de determinados métodos que são aplicados para descrever e resumir as características da amostra" (ROGERSON, 2012).

Os levantamentos de dados qualitativos foram realizados por meio de entrevistas abertas e serviram de complementação para as análises dos dados quantitativos. Nesta etapa deu-se preferência às opiniões dos entrevistados, sobre como avaliam o papel dos benefícios para os domicílios. Tratam, ainda, de questões referentes às relações de produção e consumo, organização das atividades produtivas, rendimentos e despesas dos domicílios. Também foi utilizada revisão bibliográfica sobre o tema para apoiar discussões dos dados coletados em campo. Os nomes citados no trabalho são fictícios. As entrevistas só foram realizadas a partir do consentimento dos entrevistados e após a assinatura de Termo de Consentimento Livre e Esclarecido (TCLE).

A área de estudo está localizada no município de Tefé (Figura 1). Pode-se chegar tanto por via área quanto fluvial. De avião, a duração média da viagem é de 50 minutos a 1 hora. Por via fluvial chega-se de barco recreio ${ }^{4}$, com duração média das viagens de 40 horas, ou de lancha a jato ${ }^{5}$ (expresso) com duração média das viagens de 12 horas.

\footnotetext{
${ }^{4}$ Embarcação de grande porte com capacidade para carga e passageiros.

${ }^{5}$ Lancha de alta velocidade.
} 
Figura 1: Mapa de localização da cidade da cidade de Tefé e comunidades rurais do estudo

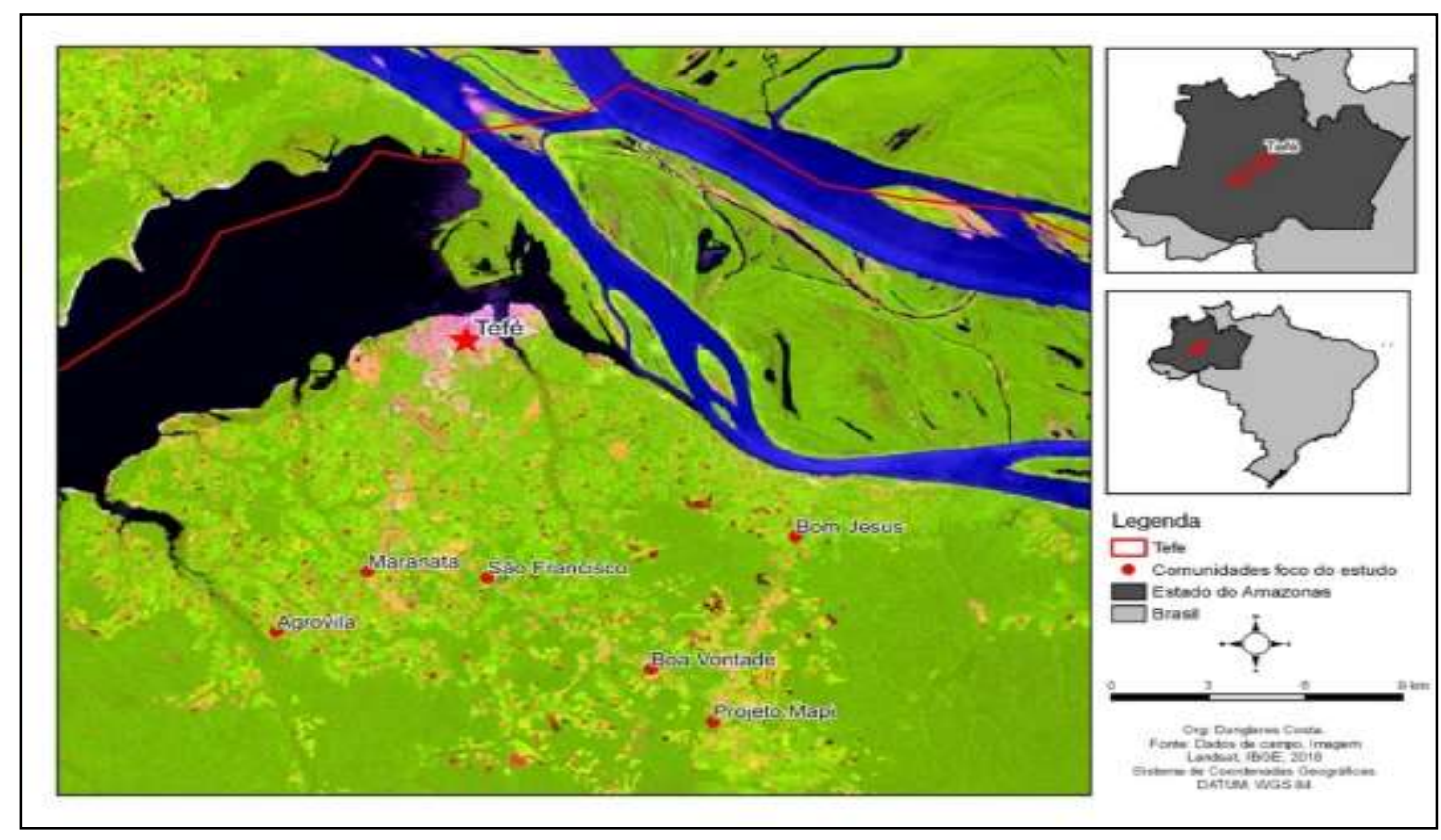

Fonte: Org.: Costa e Coelho, 2018

Compuseram a amostra deste estudo comunidades que se localizam ao longo das estradas da Agrovila e Emade, ligadas ao núcleo urbano de Tefé. São elas: Agrovila, Maranata, São Francisco, Agrovila da Emade, Bom Jesus e Boa Vontade. Foram tomados como sujeitos deste estudo cerca de $15 \%$ dos domicílios de cada comunidade. Os dados foram analisados com o apoio de programas de análise estatística e planilhas eletrônicas (Statistical Package for the Social Sciences-SPSS e Microsoft Excel). As exposições dos dados foram feitas através de gráficos e tabelas.

O levantamento de dados qualitativos foi realizado por meio de entrevistas abertas e serviu de complementação para as análises dos dados quantitativos. Os nomes citados no trabalho são fictícios, para não comprometer as famílias entrevistadas nas comunidades. Essa etapa consistiu em levantar questões referentes às relações de produção e consumo, organização das atividades produtivas, rendimentos e despesas dos domicílios. Também foram utilizadas revisão e análise bibliográfica sobre o tema para apoiar a discussão dos dados coletados em campo.

\section{UM PANORAMA SOBRE BENEFÍCIOS SOCIAIS E POPULAÇÕES RURAIS}

Este tópico faz um retrato do que foi o processo para construção e formalização de benefícios como as aposentadorias rurais, programas sociais no Brasil, a partir dos tratados 
pela Constituição de 1988. Um ponto que merece destaque, em primeiro lugar, foi a "expansão da Previdência Social aos agricultores, o setor rural ganhou força política no fim dos anos 1950 e início de 1960, quando a mobilização nacional dos trabalhadores rurais resultou na criação de diversas organizações sindicais, sendo a reforma agrária sua principal demanda". (SCHWARZER e QUERINO, 2002, p.14)

Outro ponto é o aumento na concessão de aposentadorias mencionado por Ferreira e Souza (2007), que resulta em maior seguridade social, mudanças de natalidade e envelhecimento da população e os incrementos das aposentadorias na renda das famílias rurais brasileira, como destacam:

\begin{abstract}
O aumento visível das aposentadorias é resultado do conteúdo favorável à seguridade social da Constituição de 1988 e do aumento do volume de contribuintes estimulado na década de 1970 que redundou no incremento de beneficiários na década de 1990, das mudanças demográficas, da queda na taxa de natalidade e do "envelhecimento" da população brasileira. Especial atenção é merecedora a área rural brasileira, com expressivos incrementos na participação das aposentadorias na renda domiciliar. Os anos 90-92 são ímpares, dada a magnitude de elevação dessa participação. (FERREIRA; SOUZA, 2007, p. 1007)
\end{abstract}

De acordo com Schwarzer e Querino (2002), a Constituição Federal de 1988 foi escrita após o fim do governo militar (1964-1984). O "espírito" prevalecente durante a elaboração dos seus "capítulos sociais" teve por objetivo reverter a regressividade e exclusão da política social brasileira, mediante adoção de medidas de caráter universal. Isso significava, em princípio, a introdução de um conceito mais amplo de "Seguridade Social". (SCHWARZER; QUERINO, 2002, p. 9)

Os mesmos autores destacam ainda que "os benefícios rurais expandiram-se rapidamente durante os anos 1970, chegando no fim da década com aproximadamente 800 mil benefícios por mês"; outro ponto em destaque foi a condicionalidade para concessão das aposentadorias, que reduzia a idade necessária em cinco anos para as aposentadorias por idade, sendo uma das mais importantes a aplicação do princípio da equidade de gênero. Outro ponto importante foi "o aumento do valor mínimo do benefício para o equivalente a um salário mínimo oficial" (SCHWARZER; QUERINO, 2002, p. 14-15)

Em outra linha de análise, ao estabelecer comparações de nivelamento social entre habitantes urbanos e rurais, Barros, Fiúza e Pinto (2017) esclarecem que o acesso aos direitos sociais pelas populações rurais tem sido uma das mais importantes causas do nivelamento social entre habitantes urbanos e rurais, o que também criou profundas mudanças na vida das famílias rurais. O recebimento de uma renda mensal regular de aposentadoria rural institucionalizou o que poderia ser caracterizado como novo "habitus". 
É importante compreender que ter direito e acesso a um benefício social como a aposentadoria é extremamente importante para os beneficiários, do ponto de vista da garantia de manutenção dos elementos básicos de subsistência dos grupos domésticos. Ao mesmo tempo, analisar o alcance da Previdência Social por meio das aposentadorias pode ser encarado como política pública e instrumento de incremento das economias de lugares rurais. A esse respeito, Ferreira e Souza (2007) destacam que "a Previdência Social do Brasil apresenta-se como um dos mais importantes instrumentos de política pública e base de sustentação da economia de um grande número de municípios brasileiros de baixa renda". (Ferreira e Souza, 2007, p. 987)

Assim, é papel do Estado garantir condições e intervir em questões de desigualdades presentes em nossa sociedade, seja em áreas urbanas ou rurais. Em muitos casos, os retratos que o país apresenta são resultado das ações diretas do Estado, o qual tenta, por meio de políticas públicas ou políticas de assistência social, permitir a diminuição das desigualdades sociais. No entanto, a Previdência Social esteve restrita, por muito tempo, aos setores urbanos organizados dos trabalhadores e a algumas categorias profissionais, da sua criação até o início dos anos 1960, não tendo o sentido de universalização. Após 1964, o sistema de proteção social e a Previdência Social passam por reformas e são direcionadas à unificação e universalização dos benefícios, incluindo, em 1971, os trabalhadores rurais (FERREIRA; SOUZA, 2007, p. 1007).

Políticas públicas ou políticas de assistência social estão pautadas na descrição feita por Lindo (2011), ao enfatizar que:

As políticas públicas, em geral, são aprovadas pelo Poder Legislativo, ou seja, pelos parlamentares (vereadores, deputados e senadores). Geralmente as propostas das políticas públicas partem do Poder Executivo e é esse Poder que coloca as políticas públicas em práticas. As informações necessárias ao processo de tomada de decisão dos membros do Poder Executivo, bem como a operacionalização das políticas são de responsabilidade dos servidores públicos (LINDO, 2011, p. 67).

Assim, Lindo (2011) aborda que o papel ativo do Estado para a criação e direcionamento de políticas públicas e políticas de assistência sociais como mecanismos importantes é:

\footnotetext{
Intervir em questões sociais expressas pelo conjunto de desigualdades (re) produzidas pelas contradições do modo capitalista de produção e consequentemente pelas relações sociais. Essas políticas de responsabilidade estatal devem ser apreendidas no contexto político, social, cultural e econômico atendendo à lógica do Estado que a executa de acordo com interesse de grupos e classes sociais (LINDO, 2011, p. 61).
}

Ainda a esse respeito, Pochmann (2010) destaca as transformações das condições de produção e reprodução da pobreza ao longo do tempo e enfatiza a importância das políticas públicas de combate às diferentes formas de pobreza. Segundo o autor, "o avanço das políticas públicas de caráter distributivo permitiu, em consequência, reduzir e até superar a pobreza 
extrema, quando não absoluta, mesmo sem contemplar medidas contra a concentração de renda e riqueza" (POCHMANN, 2010, p. 3). A mobilidade social é destacada por esse autor como alteração de posições de distintos segmentos populacionais no interior da estrutura social. O Gráfico 1 corrobora tal afirmativa ao apontar os indicadores de mobilidade social:

Gráfico 1: Indicador de mobilidade social em diferentes países

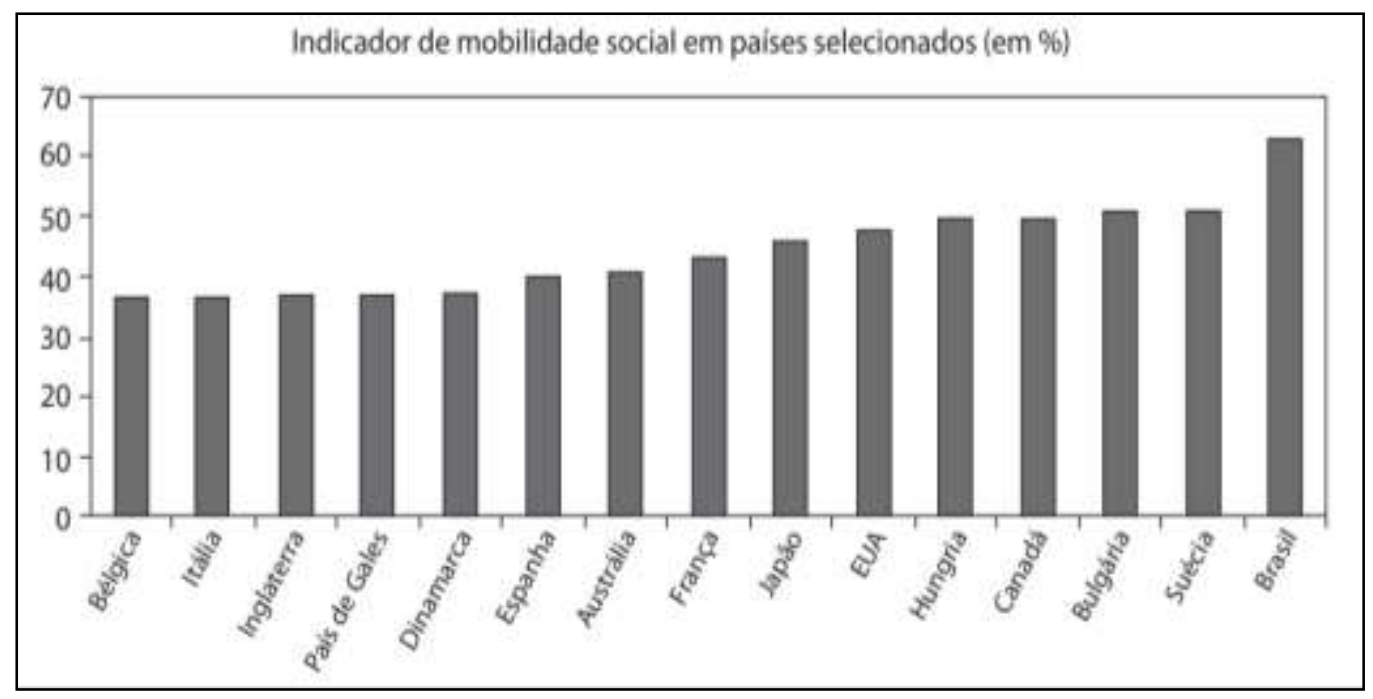

Fonte: IBGE (PNAD, 1996), apud Pochmann, 2010.

O Gráfico 1 mostra que o Brasil, por ser um país em desenvolvimento, destaca-se entre os grandes países desenvolvidos, como EUA, Bélgica, Inglaterra, Espanha e França. O Brasil apresenta mobilidade social de $62 \%$ para superar e reduzir a pobreza extrema em programas sociais, visto que esses programas são para famílias de baixa renda. A taxa de mudança social brasileira é de $62 \%$, diferente de países como Espanha $(40,7 \%)$, França $(43,7 \%)$, Estados Unidos (48,2\%), Bélgica (37\%), Inglaterra (37,6\%) e Dinamarca (37,9\%). (Pochmann, 2010, p. 638).

A mobilidade social parece tornar-se positiva, pois o Brasil, sendo um país em desenvolvimento, ao lado de países desenvolvidos destaca-se por investir nessa questão social. Como colocado por Pochmann (2010), o Brasil reduziu e até mesmo superou essa desigualdade social e teve seu cenário transformado por meio do aumento da renda e da diminuição das desigualdades nesta, impulsionados pelo aumento da renda nacional por habitante. Ao mesmo tempo, apresentou queda acentuada da desigualdade pessoal da renda entre os anos 2000 e 2010, como mostra o Gráfico 2. 
Gráfico 2: Índice de evolução da renda nacional por habitantes e desigualdade da renda.

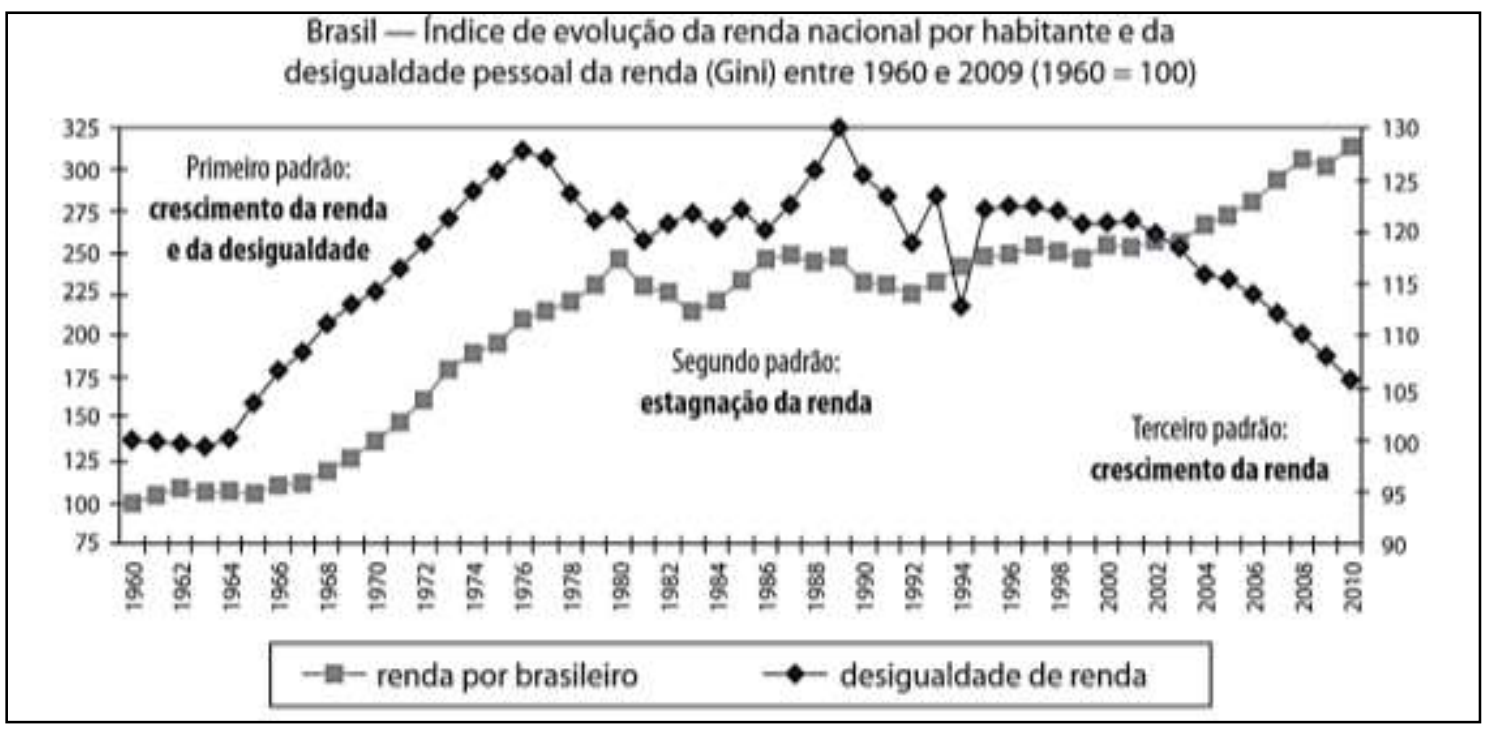

Fonte: IBGE apud Pochmann, 2010, (organizado pelos autores).

O primeiro padrão de mudança social no Gráfico 2 caracterizou-se por forte expansão da renda per capita, acompanhada de significativo crescimento da desigualdade na repartição da renda pessoal. "Durante os anos 1960 e 1980, o Brasil seguiu orientado pelo avanço do projeto de industrialização nacional com importante impacto decorrente do movimento geral de urbanização" (POCHMANN, 2010, p. 640).

O segundo padrão apresentado no Gráfico 2 reflete a mudança social ocorrida entre os anos 1981 e 2003. Durante esse período, "predominou a estagnação na variação da renda per capita acompanhada do estancamento do grau de desigualdade na repartição da renda pessoal”. (POCHMANN, 2010, p. 640).

O terceiro padrão possui como características principais a combinação da expansão da renda nacional per capita com a queda na desigualdade pessoal da renda. "Para os anos de 2004 e 2010, a renda per capita cresceu 2,9\% como média anual, enquanto a desigualdade da renda pessoal caiu 1,5\% em média ao ano". (POCHMANN, 2010, p. 641-642).

É importante notar que um componente dos rendimentos que está diretamente sujeito a normas e leis, como as aposentadorias e pensões, esteja contribuindo para aumentar a desigualdade da distribuição da renda. (Ferreira; Souza, 2007, p. 1009). Desse modo, as novas legislações trouxeram melhorias profundas para os segurados rurais. Como destacado por Schwarzer e Querino (2002), o direito à aposentadoria por idade foi estendido ao cônjuge - na concepção destes autores, na prática, significava estender o benefício à mulher -, sem importar o fato de que o chefe de família poderia estar recebendo um benefício da Previdência Social. 
Essa mudança nas regras significou uma universalização da cobertura às mulheres trabalhadoras rurais idosas e uma mudança em seu papel social.

No Brasil, atualmente, a desigualdade social de renda é reduzida através de alguns programas provenientes do governo federal direcionados às famílias de baixa renda, os chamados Programas de Transferência de Renda, como o Bolsa Família. Este e outros programas são mecanismos que contribuem para um cenário menor de desigualdade e para o acesso direto à renda.

No estado do Amazonas, com destaque para as áreas rurais, o conjunto desses mecanismos é composto pelas aposentadorias, pensões, Auxílio Doença, Salário Maternidade, Seguro Desemprego do Pescador Artesanal (Seguro Defeso), Bolsa Família, Bolsa Floresta, Bolsa Verde, entre outros. Fazem parte do conjunto de programas e benefícios sociais ligados à renda dos beneficiários, que permitem o acesso direto à renda e a garantia de maior interação com os mercados locais, maior monetarização nas trocas econômicas, maior aquisição de bens de consumo e construção de um novo perfil socioeconômico das famílias rurais.

A respeito das condicionalidades para se ter acesso a tais programas e benefícios, temos um conjunto de critérios necessário. Por exemplo, para ter acesso à aposentadoria, 0 beneficiário deve ter idade mínima de 60 anos, para os homens, e 55 anos para as mulheres, e comprovar exercício na atividade por pelo menos 15 anos.

As pensões são garantidas às pessoas em ocasiões como morte, além das pensões alimentícias. Já o Auxílio Doença é pago às pessoas que estão temporariamente incapacitadas de exercer atividades profissionais em decorrência de doença ou acidente. Sobre o Salário Maternidade, esse benefício é pago no caso de nascimento ou adoção de criança.

Para o Seguro Desemprego do Pescador Artesanal, conhecido na região de estudo como Seguro Defeso, o requisito é ser pescador associado em colônia ou associação de pescadores. O Seguro Defeso tem abrangência federal e seu objetivo principal é garantir ao segurado compensação financeira, por meio de pagamento de benefício no valor de um salário mínimo, durante os meses de interrupção de suas atividades no período reprodutivo das espécies.

O Programa Bolsa Família (PBF) é um benefício social pago às famílias de baixa renda. Para receber este benefício a condicionalidade básica é a família possuir renda per capita abaixo de $R \$ 140,00$. É um programa de transferência de renda do governo federal, estabelecido pela Medida Provisória 132, de 20 de outubro de 2003, transformada em lei em 2004, por meio da Lei Federal nำ10.836. 
Desde 2004, o benefício é concedido, em princípio, por um período de dois anos. Isso quer dizer que se espera que os agentes municipais do PBF revisitem as famílias - ou de outra forma atualizem seu cadastro - a cada dois anos, para verificar se suas condições de vida mudaram ou permanecem as mesmas. Na prática, nem todos os municípios mantêm este grau de agilidade, e há famílias beneficiárias no PBF que passam muito tempo sem receberem visitas do agente social (Soares; Sátyro, 2009, p. 13).

Um ponto importante no que se refere ao Bolsa Família é a vinculação do cartão do beneficiário ao nome da mulher, o que traz significativas mudanças dentro dos domicílios. Como já destacado por Rego e Pinzani (2013) na obra "Vozes do Bolsa Família: autonomia, dinheiro e cidadania", na qual destaca a relação de um "dispositivo de transferência de renda" e um possível "empoderamento" das mulheres beneficiárias.

Os benefícios Bolsa Floresta e Bolsa Verde são pagos às pessoas que se comprometem com a redução de desmatamento em áreas de Unidades de Conservação. Estes ingressos estão ligados ao programa REDD+, Redução das Emissões Derivadas de Desmatamento e Degradação, e sua principal premissa é recompensar financeiramente ( $R \$ 50,00$ mensais) moradores de unidades de conservação do estado do Amazonas pelo seu papel na conservação das florestas (VIANA, 2008).

De acordo com SILVA (2009), no Brasil, a Previdência Social foi implantada em 1923, com a Lei Eloy Chaves. Desde então, o sistema de previdência passou por gradativas e significativas mudanças.

\begin{abstract}
Apesar de o sistema previdenciário brasileiro existir desde o final do século XVIII, somente a partir da Constituição de 1988 os trabalhadores rurais passaram a ter os mesmos direitos que os trabalhadores urbanos aos benefícios da Previdência Social. A partir de então, houve a inclusão dos trabalhadores rurais e dos segurados em regime de economia familiar (considerados segurados especiais) nos planos de benefícios do Regime Geral de Previdência Social (RGPS). Com as novas regras constitucionais, as mulheres também passaram a ter direito à aposentadoria. (SCHNEIDER, 2003, p. 2).
\end{abstract}

Desse modo, os impactos dos benefícios previdenciários deram-se de forma positiva para muitas pessoas, os benefícios concedidos permitiram amortização das desigualdades sociais e outra perspectiva de vida, apesar do índice de pobreza e da má distribuição de renda, ainda altos, e as pessoas estarem inseridas em um contexto de desigualdades sociais, principalmente em áreas rurais, pela ausência de políticas públicas que garantam condições adequadas de vida a todos.

O contexto socioeconômico em que vivem os trabalhadores rurais no Brasil é marcado por diversas dificuldades, entre elas o alto grau de concentração da posse de terras, 0 baixo nível de acesso ao crédito, a carência de assistência técnica, a concentração de renda e a pobreza rural (SILVA, 2009, p. 2). 
Os benefícios sociais são mecanismos que garantem ao cidadão, em alguns casos, acesso a direitos e, em outros, permitem a implementação de políticas que visam à suavização de desigualdades, como no caso dos benefícios de transferência de renda. Para muitas pessoas do meio rural, são tidos como uma "esperança" e segurança em casos de necessidades.

O Bolsa Família, Bolsa Floresta e Seguro Defeso são vistos ainda, em casos específicos, como uma segurança monetária dentro do contexto da organização social e econômica das famílias beneficiárias, principalmente nos momentos em que seus modos de vidas e subsistência são comprometidos. A este respeito, Silva (2004) destaca:

\begin{abstract}
O benefício de um salário mínimo aos trabalhadores rurais representou uma esperança em suas vidas e na de suas famílias, incrementou sua renda, ajudando na manutenção de seu sustento e de suas atividades e possibilitando melhores perspectivas para enfrentarem as adversidades nos períodos de estiagem em regiões de baixas oportunidades de emprego e renda (SILVA, 2004, p. 2).
\end{abstract}

No caso do benefício Bolsa Família, entre outras questões que envolvem o programa, estão suas condicionalidades para que haja garantia de recebimento dos rendimentos mensais, como a permanência dos filhos na escola, com carga horária de frequência sempre mantida em torno de $85 \%$ da carga horária total mensal, além da garantia de manutenção da carteira de vacinação dos filhos. Essas condicionalidades geram significativas mudanças e saldo positivo, pois ao mesmo tempo que garantem uma renda mínima às famílias, estabelecem o cumprimento de condicionalidades ligadas à educação e saúde.

A experiência do Bolsa Família fornece um rendimento regular para a grande maioria das mulheres. Nas palavras de Rego e Pinzani (2013, p. 17), a renda regular em dinheiro é um importante instrumento de autonomia individual e política para os beneficiários. Contudo, ainda continuam pobres e carentes de inúmeros direitos.

Nesses recortes que se apresentam as populações de cada época estudada, percebese que as evoluções são pouco visíveis, mas acontece aos poucos. Partindo disso, vamos nos deparar com estudos relacionados às populações amazônicas, pois serão alvos também deste estudo em relação aos tipos de populações que são conhecidas e o contexto social em que se encontram. De acordo com Lima (2006):

No médio Solimões as populações podem ser "classificadas tanto como cabocla quanto como população tradicional. Sobre a classificação de cabocla está relacionada "ao campesinato amazônico de origem colonial, habitantes principalmente das margens dos rios. Enquanto população tradicional, trata-se de uma população regional, amazônica, com longa história de convivência com o ambiente natural". (LIMA, 2006, p. 1).

As populações rurais e/ou ribeirinhas têm em sua orientação econômica características de populações camponesas. Nas palavras de Lima e Peralta (2016), "uma economia 
doméstica, que tem as características de um campesinato moderno: produz para vender e vende para comprar. A produção é autônoma, e o grupo familiar é a unidade de referência para a produção e o consumo" (LIMA; PERALTA, 2016, p. 45).

O camponês é um trabalhador que está diretamente envolvido com a natureza, sobrevive da agricultura, e, devido ser esse o meio de sua subsistência, ao longo da História foi considerado um povo oprimido, dominado pela sociedade da época (MOURA, 1988, p.13). O autor ainda destaca que pode haver várias descrições de camponês:

Como um cultivador de pequenas áreas juntamente com sua família, também denominado por outros autores como camponês parcelar. Quando este produz somente para o sustento, em terras no qual não tem a posse, é chamado de posseiro. Em Ciências Sociais é apresentado como cultivador que trabalha a terra, identificando que o camponês não é um proprietário fundiário capitalista (MOURA, 1988 p. 509).

Nas descrições feitas por Moura (1988) sobre o camponês parcelar ainda é possível nos dias atuais encontrar trabalhadores nesse mesmo ritmo, seguindo esse cenário de trabalho, que há muito tempo nos deparamos, por não terem terra própria para trabalhar. Sempre trabalhando nas terras alheias, produzindo somente para a sua subsistência familiar.

Por outro lado, as famílias com essas características socioeconômicas não se dedicam somente a atividades agrícolas, à pesca, à coleta de produtos florestais e a relações que se restringem a atividades ligadas a práticas produtivas. Estão presentes grupos familiares que desenvolvem outras atividades e formas de trabalho para seu autoconsumo, que trabalham com mecanismos de trabalhos realizados com pagamentos por dias trabalhados (diárias), atividades de comércios de mercadorias com compra de produção nas comunidades rurais e venda desta produção em áreas urbanas, entre outras.

A respeito dessas diversas formas de atuação e trabalho, o camponês é capaz de desenvolver várias maneiras de atividades e trabalho para sua subsistência tanto no meio urbano quanto no meio rural. Como nos aponta Thomaz Júnior (2014), "podemos oferecer um entendimento crítico em relação às diferentes formas de expressão e manifestação do trabalho, ou uma análise das formas, que se cristalizam no campo ou na cidade". Nesse mesmo sentido, o autor destaca que existem desafios de compreender esse cenário para entender "os desafios da fluidez do trabalho, ou o movimento do trabalho que nos escapa"... "porque se congela as imagens, ou seja, ou ele é camponês aqui, ou ele é assalariado ali, e muitas vezes ele, o trabalhador, é as duas coisas ao mesmo tempo". (THOMAZ JÚNIOR, 2014, p. 6).

Nesse mesmo sentido, Coelho e Peralta (2014) destacam que as escolhas por atividades e empenhos à produção dos domicílios no médio Solimões estão relacionadas às escolhas subjetivas dos grupos domésticos. Os produtores são motivados por racionalidades econômicas "orientadas para o consumo (do grupo doméstico), para as relações de 
reciprocidade, organizada no parentesco, e não separam as diversas esferas do mundo social econômica, política, religiosa" (COELHO; PERALTA, 2014).

Neste cenário de trabalho, as famílias se organizam da melhor maneira para atingir 0 seu legado produtivo. Assim, elas se organizam entre homens e mulheres para desenvolver as atividades produtivas, para construir e alimentar a sua família. Estes trabalhos estão relacionados com cada membro da família ousando atingir ou não as metas de trabalhos para seu principal objetivo, que é de manutenção do grupo familiar.

Essas famílias têm, por meio da produção familiar, parte de suas necessidades de consumo atendidas. Desempenham uma diversidade de estratégias econômicas, visando à diminuição de riscos; dessa forma, o valor do trabalho e dos bens de consumo variam em virtude de se ter ou não atingido as necessidades do grupo (PERALTA, 2012).

A produção camponesa é a base da família rural. Os trabalhos são realizados ou produzidos mediante a necessidade das famílias. Se elas precisam comprar algum material de valor ou bem, desenvolvem um pouco mais de trabalho para a compra do objeto. Se não precisam, trabalham somente para a compra de produtos para a subsistência.

Para ajudar também no sustento da família, percebeu-se que os benefícios são de grande importância neste contexto, pois eles corroboram na renda e na desenvoltura dos domicílios.

No contexto da dedicação às atividades produtivas dos grupos familiares, a presença de benefícios sociais na economia desses grupos domésticos está diretamente relacionada à maior ou menor dedicação às atividades produtivas, dependendo das necessidades de consumo dos grupos domésticos, como mencionam Lima e Peralta (2016):

A transferência direta de renda pode alterar o volume da produção doméstica, influenciando tanto na sua redução quanto no aumento, dependendo de como se dá a relação entre trabalho e consumo doméstico. Como a produção dos ribeirinhos é destinada para custear o seu consumo, enquanto a demanda de consumo socialmente necessário for maior que a penosidade do trabalho, o recebimento de benefícios não deve influenciar na redução da produção. Se, ao contrário, a produção aumentar, podemos concluir que a expectativa de consumo é maior do que o consumo propiciado pela renda acrescida dos benefícios (LIMA; PERALTA, 2016, p. 45).

Nessa discussão, Oliveira (2007) destaca que:

A sobrevivência é o limite para a produção camponesa no campo, e não o lucro médio. No trabalho camponês, uma parte da produção agrícola entra no consumo direto do produtor, do camponês, como meio de subsistência imediata, e a outra parte, o excedente, sob a forma de mercadoria, é comercializada (OLIVEIRA, 2007, p. 40).

O contexto dessas relações não está baseado na lógica capitalista de produção, como aponta Oliveira (2007):

Por isso é mister a distinção entre a produção camponesa e a produção capitalista. $\mathrm{Na}$ produção capitalista, ocorre o movimento de circulação do capital expresso nas fórmulas: 
$D-M-D$ na sua versão simples, e $D-M-D$ ' na sua versão ampliada. Já na produção camponesa, se está diante da seguinte fórmula $M-D-M$, ou seja, a forma simples de circulação das mercadorias, onde a conversão de mercadorias em dinheiro se faz com a finalidade de se poder obter os meios para adquirir outras mercadorias igualmente necessárias à satisfação de necessidades. É, pois, um movimento do vender para comprar (Oliveira, 2007, p. 40).

Diante disso, o cenário na região do médio Solimões, dentro das relações de produção e consumo dos grupos familiares, e os rendimentos monetários provenientes dos benefícios sociais recebidos pelas famílias, pode imprimir relações sociais e econômicas que são estabelecidas com a frequência dos ingressos regulares desses benefícios sociais. Os benefícios que as famílias recebem, somados às suas produções, dão mais estabilidade financeira aos grupos familiares na região.

É importante ressaltar que, no Brasil, o recebimento de um benefício previdenciário não obriga o indivíduo a abandonar a força de trabalho (SCHWARZER; QUERINO, 2002, p. 33). Nesse caso, os benefícios do governo federal vêm contribuindo com as famílias na renda nos domicílios, pois, somados às outras atividades que eles produzem, conseguem suprir as suas necessidades de consumo.

\section{A ECONOMIA DOMÉSTICA DE GRUPOS RURAIS NO MÉDIO SOLIMÕES}

A base econômica das famílias na região do médio Solimões dá-se por trabalhos familiares domésticos, produção rural, sendo a maioria de sua produção sempre destinada ao consumo, e pequena parte destinada à venda que mais tarde resultaria na aquisição de itens voltados ao consumo dos grupos. Conforme Lima (2006):

A principal característica da economia doméstica [...] é o fato de ser orientada para o consumo do grupo doméstico que a realiza. Em cada casa os moradores trabalham para atender suas próprias demandas de consumo. A produção para a venda e a produção para o autoconsumo são usadas para alimentar, vestir, medicar e dar conforto à existência dos que moram sob um mesmo teto (LIMA, 2006, p. 1-2).

A base da renda familiar se produz no trabalho coletivo, feito por pais e filhos de uma casa ou parentesco próximos, ou por vizinhos, mediante trocas de trabalho, sendo este dividido e organizado por sexo (homens-mulheres).

O parentesco permite a inclusão e o pertencimento a um grupo local (formado pelos moradores da "comunidade", como são chamados os assentamentos rurais na região), e este pertencimento confere o direito de apropriação dos recursos naturais no território ocupado. [...]. Entretanto, o parentesco não é o único meio de se estabelecer em uma localidade (Lima, 2006, p.147).

Uma pessoa, não aparentada a nenhum morador do lugar, pode solicitar que o grupo lhe conceda permissão de entrada, e, nesses casos, é a residência que atribui o direito de apropriação dos recursos naturais [...], "onde todas as casas de um mesmo lugar exercem, por princípio, os mesmos direitos de acesso e usufruto dos recursos naturais" (Lima, 2006, p. 03). 
Segundo Moura (1988), em “A Morada e a Terra”, o modo de vida do camponês mostra que no trabalho existe uma divisão familiar, com configurações diferentes em cada cultura, mas tendo homens, mulheres e crianças como responsáveis pelo sustento da família.

Assim, o camponês não almeja o crescimento econômico; sua renda, oriunda da venda da sua produção, tem como principal propósito garantir a sobrevivência do núcleo familiar. O camponês determina seu trabalho e suas produções dependendo da sua necessidade para o seu sustento, porém não é capitalista.

Os camponeses têm relação de responsabilidade com a natureza, seu projeto de sobrevivência é baseado na unidade familiar, existe cooperação e solidariedade com as outras pessoas e familiares. Os camponeses são "atores sociais, que constroem os processos de mudança social, caracterizados principalmente pela resistência e autonomia para construção de sua própria história enquanto classe social" (MOURA, 1988, p. 513)

Segundo Lima (2006), as relações de troca entre os grupos domésticos são principalmente de natureza não monetária. Ao analisar as relações socioeconômicas de populações rurais do médio Solimões, destaca que "as doações de peixes e caças, as ajudas no trabalho ou trocas de dias, o trabalho de parteiras e as curas de rezadores são trocas orientadas pelo princípio da reciprocidade e expressam o modelo ideal de relações sociais horizontais". (Lima, 2006, p. 04).

Essas relações de troca entre os familiares e domicílios se produzem de forma que os mesmos apresentam uma horizontalidade no meio rural ou nas próprias comunidades, como são chamadas. As horizontalidades podem ser vistas através das trocas de serviço e alimentos, além do bem comum entre todos, de maneira uniforme, e uma boa convivência nas comunidades.

É possível suscitar que entre as famílias todos convivam de maneira harmoniosa, conforme seus costumes e culturas perpassadas pelos mais antigos. A seguir, será realizada uma análise dos impactos dos benefícios sociais vinculados à economia doméstica das famílias inseridas no meio rural.

\section{IMPACTO DOS BENEFÍCIOS SOCIAIS NA ECONOMIA DAS FAMÍLIAS DAS COMUNIDADES DA ESTRADA DA AGROVILA E ESTRADA DA EMADE}

Para descrição do cenário da economia doméstica das famílias rurais de Tefé, foram analisadas as principais despesas, ingresso monetário, a composição de patrimônio dos domicílios, presença de benefício, principal fonte de renda, atividades produtivas, rendimentos 
e faixa etária dos chefes dos domicílios e, por fim, uma análise sobre a importância dos benefícios para os entrevistados.

Gráfico 3: Faixas etária dos entrevistados.

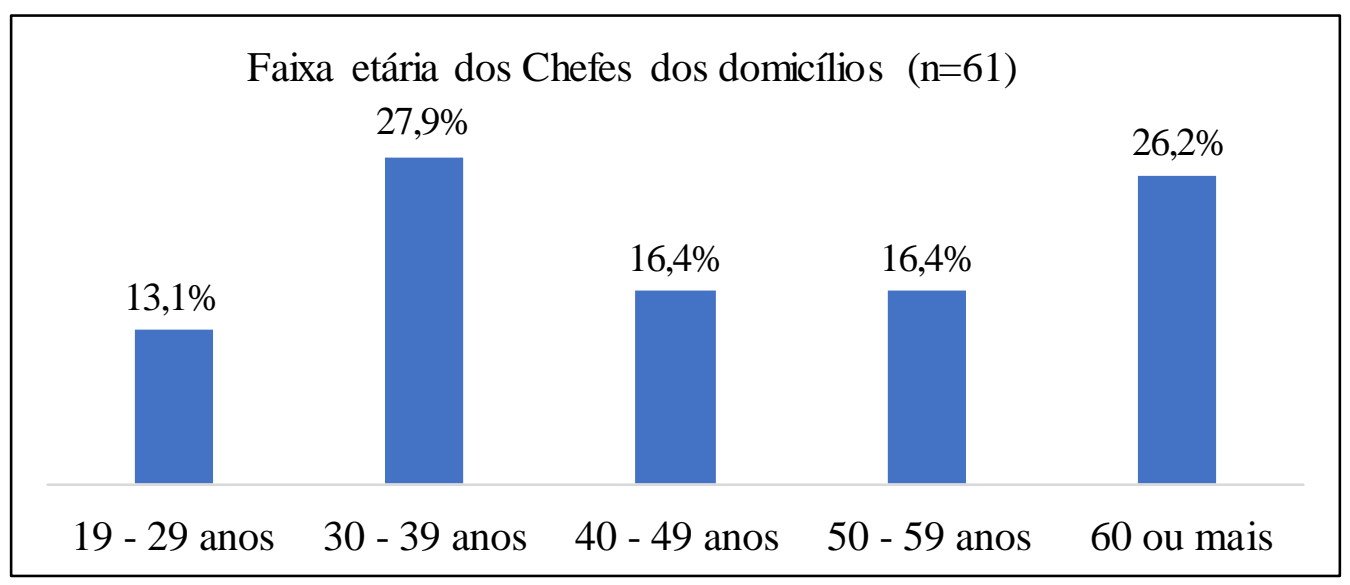

Fonte: COSTA; COELHO, 2018.

O Gráfico 3 destaca a faixa etária dos chefes das famílias, que estão distribuídos por faixa de idade, em ordem crescente na análise. Na faixa de 19-29 anos estão concentrados cerca de $13,1 \%$ dos entrevistados, enquanto $27,9 \%$ se encontram com idade entre $30-39$ anos. Já 16,4\% estão na faixa de idade de 40-49 anos, e outros 16,4\% entre 50-59 anos. Por fim, 26,2\% têm 60 anos ou mais. Todos ativos economicamente. Dentre esses citados por último, destaca-se que ainda estão em pleno exercício na atividade rural. Podemos, ainda, citar outros trabalhos desenvolvidos por eles, como a criação de galinha, que compõe os gastos dentro dos grupos familiares da área de estudo, cujos itens estão descritos no Gráfico 4:

Gráfico 4: Composição de Despesas Domésticas.

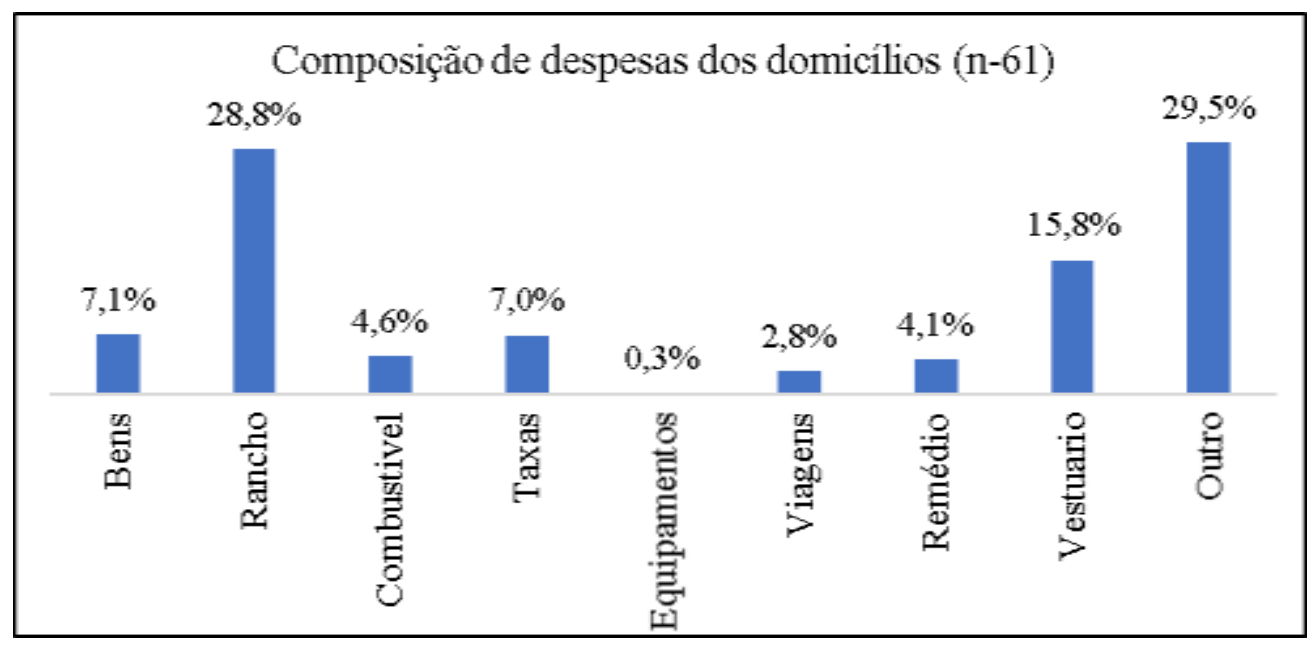

Fonte: Costa e Coelho, 2018 
A composição de gastos por domicílios está estruturada na representação individual que cada item corresponde no total de despesas dos grupos familiares. Um dos itens que compõe as despesas é o rancho ${ }^{6}$, que representou $28,8 \%$ de todos os gastos médios dos domicílios. Constituem como itens do rancho, alimentação e materiais de higiene e limpeza. Outro item importante refere-se a Outros, descritos como gastos com construção e tratamentos de saúde, por exemplo, que corresponderam aos maiores do domicílio, com 29,5\% do gasto total da casa. Outros itens com destaque foram $15,8 \%$ de despesas em vestuário; $7,1 \%$ com bens de patrimônio doméstico, seguido por gastos com taxas, 7\%; e combustível, com 4,6\% do gasto total do domicílio.

Tabela 1: Gastos médios em $\mathrm{R} \$$ por item de despesas.

\begin{tabular}{l|l|l}
\hline Gasto médio em $\mathbf{R} \$$ & Média Mensal & \multicolumn{2}{|l}{ Média anual } \\
\hline Bens & $\mathrm{R} \$ 70,8$ & $\mathrm{R} \$ \quad 849,2$ \\
\hline Rancho & $\mathrm{R} \$ 289,5$ & $\mathrm{R} \$ 3.474,1$ \\
\hline Combustível & $\mathrm{R} \$ 46,1$ & $\mathrm{R} \$ \quad 553,0$ \\
\hline Taxas & $\mathrm{R} \$ 69,6$ & $\mathrm{R} \$ \quad 835,0$ \\
\hline Equipamentos & $\mathrm{R} \$ 2,7$ & $\mathrm{R} \$ 32,2$ \\
\hline Viagens & $\mathrm{R} \$ 28,3$ & $\mathrm{R} \$ 340,0$ \\
\hline Remédio & $\mathrm{R} \$ 40,6$ & $\mathrm{R} \$ 487,6$ \\
\hline Vestuário & $\mathrm{R} \$ 158,1$ & $\mathrm{R} \$ 1.897,1$ \\
\hline $\begin{array}{l}\text { Outros } \\
\text { Fonte.: Costa e Coelho, } 2018\end{array}$ & $\mathrm{R} \$ 295,0$ & $\mathrm{R} \$ 3.539,0$
\end{tabular}

Pode ser observado que o gasto médio mensal e anual com outros gastos foi de $\mathrm{R} \$$ 295,00 por famílias, com uma média anual de 3.539,00. Nesta análise, gastos com construção e tratamento de saúde foram os mais significativos para 2017. Enquanto o gasto médio com itens que compõem o rancho foi de $\mathrm{R} \$ 289,5$ mensais e de $\mathrm{R} \$ 3.474,1$ ao ano, gastos com itens de vestuários foram de $R \$ 158,1$ ao mês e de $R \$ 1.897,1$ reais por ano.

Os gastos com bens de patrimônio foram de $R \$ 70,8$ ao mês e de $R \$ 849,2$ ao ano. Seguidos dos gastos com as taxas, que corresponderam a gastos médios de $R \$ 69,6$ mensais e $R \$ 835,0$ anuais. Estas taxas são compostas por taxas com energia elétrica (todas as comunidades pesquisadas possuem energia elétrica), taxas com associações e sindicatos rurais, colônias e dízimos religiosos.

\footnotetext{
${ }^{6} \mathrm{Na}$ região do médio Solimões, o rancho representa os itens da cesta básica das famílias. Estes itens são geralmente adquiridos no mercado por meio de trocas monetárias.
} 
Os gastos com combustíveis foram de $R \$ 46,1$ mensais e $R \$ 553,0$ por ano. Onde menos se gastou em 2017 foi com equipamentos de trabalho, $R \$ 2,7$ em média por mês e $R \$$ 32,2 ao ano; viagens totalizaram gastos de $R \$ 28,3$ ao mês e $R \$ 340,0$ por ano; e remédios com gastos médios de $R \$ 40,6$ por mês e de $R \$ 487,6$ ao ano.

Como mencionado, parte dos gastos dos domicílios estudados é com bens de patrimônio doméstico, apresentados na Tabela 2. Estes Bens são descritos como bens duráveis. Exemplos: geladeira, televisão, fogão, entre outros.

Tabela 2: Bens de patrimônio domésticos.

\begin{tabular}{l|c}
\hline Bens de patrimônio & Frequência \\
\hline Motor de Centro & $1,6 \%$ \\
\hline Motor de Luz & $6,6 \%$ \\
\hline Televisão & $93,4 \%$ \\
\hline Freezer & $31,1 \%$ \\
Geladeira & $91,8 \%$ \\
\hline Máquina de Lavar & $60,7 \%$ \\
\hline Fogão a Gás & $96,6 \%$ \\
\hline Cama & $93,4 \%$ \\
Celular & $70,5 \%$ \\
\hline Motosserra & $19,7 \%$ \\
\hline Poupança & $13,1 \%$ \\
\hline Rabeta & $24,6 \%$ \\
\hline
\end{tabular}

Org.: Costa e Coelho, 2018.

A Tabela 2 mostra a presença de patrimônio doméstico que os domicílios adquiriram em 2017. Nota-se que o bem que se destaca nos patrimônios domésticos é o fogão a gás, com 96,6\%. Podemos perceber que nas comunidades há elevadíssimo número de pessoas que fazem uso do fogão a gás, por ser mais prático e também por fazer parte de bem de consumo dos moradores. O segundo bem mais presente é a televisão e a cama, com 93,4\% cada um dos itens. Já o item geladeira está presente em $91,8 \%$ dos domicílios analisados pela pesquisa, e o freezer se faz presente em apenas 31,1\% dos domicílios. O item celular está presente em $70,5 \%$ dos domicílios; neste quesito, há destaque para celulares móveis e celulares fixos (celular rural $^{7}$ ).

Há, ainda, forte presença de máquina de lavar, pois nossos dados apontam que 60,7\% dos domicílios possuem este equipamento. Talvez estejamos diante de um possível "nivelamento aproximado entre os estilos de vida rurais e urbanos" já mencionado por Barros,

\footnotetext{
${ }^{7}$ O celular rural se diferencia do outro modelo móvel em especial por não poder sair dos domicílios, como se pode fazer como o celular convencional. Estes aparelhos fixos utilizam sinais das telefonias móveis, mas isso só é possível com o auxílio de uma antena de alta capacidade que capta o sinal emitido do centro urbano de Tefé.
} 
Fiúza e Pinto (2017), em que a garantia fornecida pelo recebimento de um benefício, naquele estudo, o da pensão mensal, contribuiu para um nivelamento aproximado entre estilos de vida rurais e urbanos nesses pequenos municípios com economias predominantemente agrícolas, podendo ser uma explicação para a presença significativa do bem de consumo citado anteriormente.

Itens como motosserra (19,7\%), poupança $(13,1 \%)$, motor rabeta ${ }^{8}(24,6 \%)$, motor de centro $^{9}(1,6 \%)$ e motor de luz $(6,6 \%)$ também estão presentes nas famílias entrevistadas. Foi possível perceber neste cenário contemporâneo que já houve muitas mudanças nos domicílios analisados, sendo cada vez mais comum a presença de itens do ambiente urbano no meio rural.

Sobre a aquisição dos bens de patrimônio, buscamos identificar se os domicílios adquiriram bens em 2017. Constatamos que, da amostra de análise, 41\% dos entrevistados adquiriram bem de patrimônio doméstico para o ano de análise. A compra desses itens é feita por duas vias principais, à vista ou a prazo. Dos entrevistados que adquiriram um patrimônio doméstico, $42 \%$ pagaram à vista, enquanto 58\% optaram pelo pagamento a prazo.

Essa forma de pagamento a prazo está relacionada aos cartões de benefícios, que são elementos que garantem uma renda mensal frequente e permitem crédito no mercado. Como destacado por COELHO e PERALTA (2016) ao analisarem mudanças nas relações comerciais de pequenos produtores rurais no médio Solimões, "os benefícios representam ingressos regulares e permitem negociar mercadorias a crédito direto no mercado". (Coelho e Peralta, 2016, p. 17).

Sobre a análise da composição dos rendimentos dos domicílios analisados (Gráfico 5), como já destacado, compõem rendimentos dos domicílios ingressos provenientes de benefícios sociais, rendimentos resultantes das atividades produtivas (agricultura, pesca, extrativismo, entre outros), renda de comércio, salário e diárias.

Cabe destacar que os rendimentos monetários dos grupos não são o único elemento responsável pela manutenção dos grupos domésticos, uma vez que as necessidades dos grupos são atendidas em sua grande parte pelo que os próprios grupos produzem.

\footnotetext{
${ }^{8}$ Motor de baixa potência usado em pequenas embarcações (canoas), muito comum em toda a região amazônica.

${ }^{9}$ Motor de maior potência, usado para tracionar embarcações de maior capacidade, sendo denominado batelão nessa região.
} 
Gráfico 5: Composição de rendimentos por fonte de ingresso. $52,5 \%$

Composição de Rendimentos dos Domicílios (n=61)

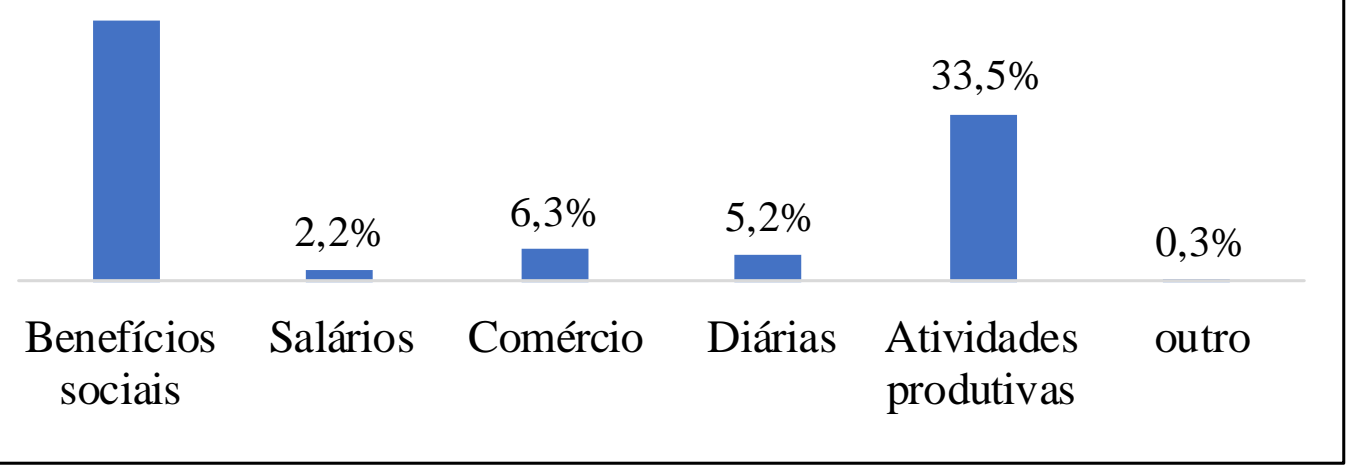

Org.: Costa e Coelho, 2018.

Os ingressos mais significativos para a renda dos domicílios são provenientes dos benefícios sociais, $52,5 \%$. A segunda maior fonte de ingresso vem das atividades produtivas que realizam e correspondem a $33,5 \%$ dos ingressos monetários. As atividades de comércio compõem $6,3 \%$ dos rendimentos, e os ingressos provenientes de diárias ${ }^{10}$ somam $5,2 \%$ da renda do domicílio. Salários integram 2,2\% da renda, e Outros (serviço de transporte em carrocinha), apenas $0,3 \%$.

Uma das questões levantadas por esta pesquisa foi sobre as principais fontes de renda declaradas pelos entrevistados. Esta informação serve para identificarmos quais fontes de renda os entrevistados declaram ser as principais da família. De acordo com eles, são os benefícios sociais, correspondendo a $49,2 \%$ dos domicílios entrevistados.

O trabalho remunerado foi declarado como principal fonte de renda de $23 \%$ dos domicílios, a agricultura, 21,3\%, e as atividades de pesca e comércio corresponderam, ambas, a 3,3\%. O rendimento monetário de cada um desses elementos constituintes da renda das famílias está descrito na Tabela 3.

Tabela 3: Rendimentos Médio Mensal e Anual dos Domicílios.

\begin{tabular}{l|l|l}
\hline Rendimentos médios & Mensal & Anual \\
\hline Benefícios sociais & $\mathrm{R} \$ 669$ & $\mathrm{R} \$ 8.026$ \\
\hline Salários & $\mathrm{R} \$ 28$ & $\mathrm{R} \$ 331$ \\
\hline Comércio & $\mathrm{R} \$ 80$ & $\mathrm{R} \$ 964$ \\
\hline Diárias & $\mathrm{R} \$ 66$ & $\mathrm{R} \$ 793$ \\
\hline Atividades produtivas & $\mathrm{R} \$ 427$ & $\mathrm{R} \$ 5.122$ \\
\hline Outros & $\mathrm{R} \$ 4$ & $\mathrm{R} \$ 48$
\end{tabular}

Fonte: Costa e Coelho, 2018

${ }^{10}$ As diárias são rendimentos pagos por dias trabalhados e não contemplam regimes formais de empregos. 
Nesta Tabela é feita a análise pela fonte de ingresso monetário e se dá com o valor médio recebido mensal e anualmente por cada domicílio. O valor de ingresso dos benefícios é de $R \$ 669,00$ mensais por domicilio, e um valor médio anual de $R \$ 8.026,00$. Já as atividades produtivas rendem em média $R \$ 427,00$ mensais e cerca de $R \$ 5.122,00$ anuais por família. $O$ comércio aparece com rendimentos médios mensais de $R \$ 80,00$ e cerca de $R \$ 964,00$ ao ano. O valor proveniente de diárias representa $R \$ 66,00$ mensais na renda dos domicílios e em torno de $R \$ 793,00$ ao ano. Os salários rendem cerca de $R \$ 28,00$ mensais e em torno de $R \$ 331,00$ anualmente. Outras fontes de renda geram receita de apenas $R \$ 4,00$ reais ao mês e $\mathrm{R} \$ 48,00$ em média, a cada domicílio ao ano.

Gráfico 6: Contribuição percentual dos ingressos de benefícios sociais

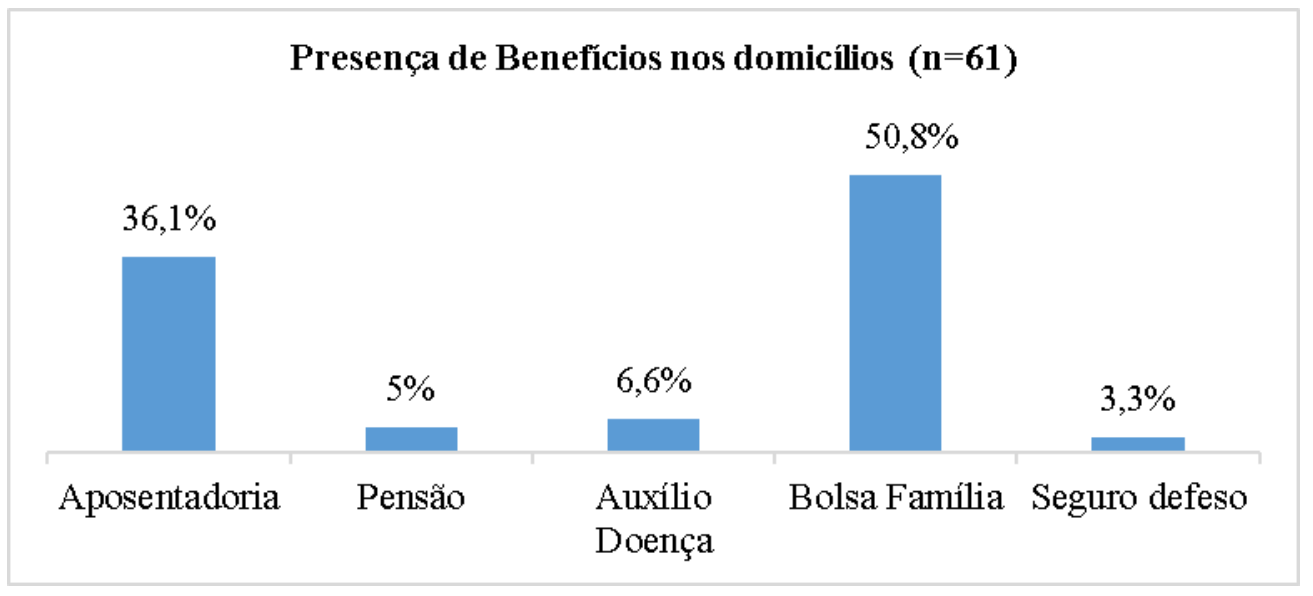

Fonte: Costa e Coelho, 2018.

O Gráfico 6 possibilita identificar que os benefícios sociais são a maior fonte de ingresso dos domicílios analisados. Observa-se que o benefício social Bolsa Família é o mais presente nas famílias, com percentual de 50,8\%, seguido da aposentadoria, com 36,1\%. O Auxílio Doença foi identificado em 6,6\% dos domicílios entrevistados, a pensão se faz presente em 5\%, e o Seguro Defeso, em 3,3\% das famílias entrevistadas. Grande parte das famílias possue o benefício citado, tanto o Bolsa Família quanto a aposentadoria.

A contribuição de cada benefício para os ingressos monetários dos grupos domésticos pode ser analisada no gráfico 7, que evidencia que as aposentadorias contribuem com 62,7\% de todos os ingressos de benefícios sociais à renda dos domicílios, enquanto o Bolsa Família corresponde com 22,2\% dos rendimentos provenientes do benefício. O Auxílio Doença somou 9,1\% de ingresso na renda; Pensão, 4,4\% de ingresso; e o Seguro Defeso com 1,6\% de ingresso dos benefícios. Notou-se que a aposentadoria se destacou porque o benefício é proveniente de um salário mínimo, por isso esse percentual mais elevado. 
Gráfico 7: Contribuição percentual dos ingressos de benefícios sociais

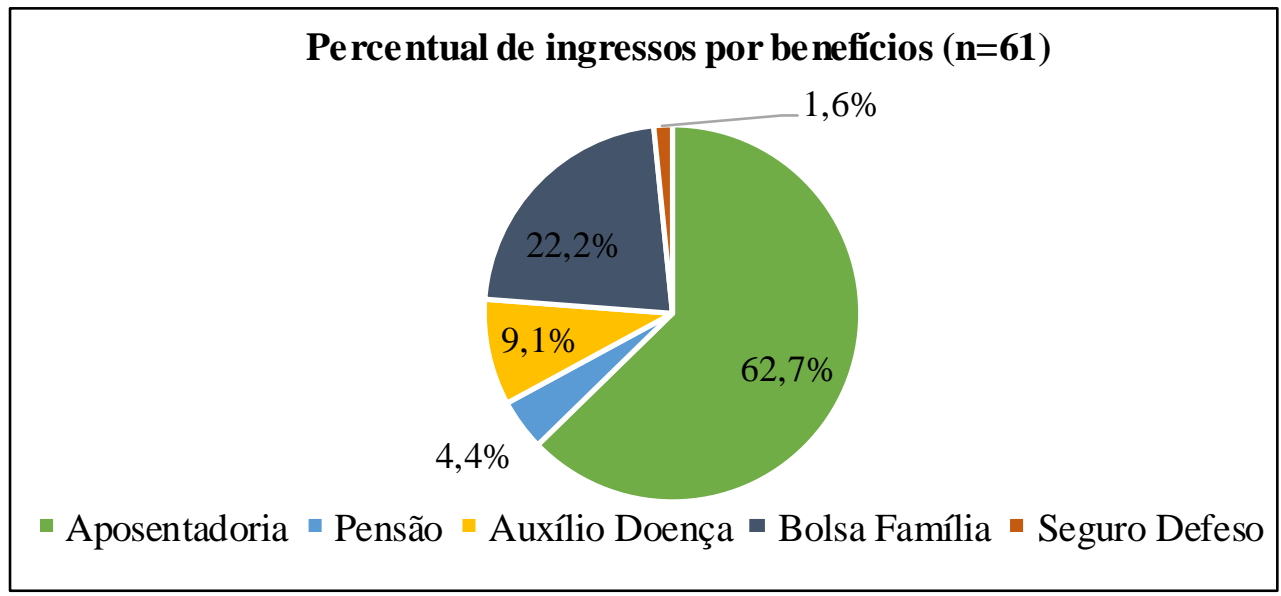

Fonte: Costa e Coelho, 2018

O cenário brasileiro indica, de acordo com WEISSHEIMER (2006), redução da desigualdade verificada nos últimos anos, sendo tal cenário resultado de um conjunto de políticas públicas e decisões na área econômica. Destacam-se aí programas como o Bolsa Família e políticas como a do aumento do salário mínimo e o impacto que esse aumento teve no pagamento de benefícios da Previdência Social.

Com relação aos ingressos em $\mathrm{R} \$$ de benefícios sociais, a Tabela 4 apresenta-se de forma que os benefícios são descritos de acordo com a renda e sua média mensal e anual.

Tabela 4: Ingressos monetários por benefício

\begin{tabular}{l|l|l}
\hline Ingressos monetários por benefícios & \multicolumn{1}{|c}{ Mensal } & \multicolumn{1}{c}{ Anual } \\
\hline Aposentadoria & $\mathrm{R} \$ 420,00$ & $\mathrm{R} \$ 5.037,00$ \\
\hline Pensão & $\mathrm{R} \$ 29,00$ & $\mathrm{R} \$ 353,00$ \\
\hline Auxílio Doença & $\mathrm{R} \$ 60,00$ & $\mathrm{R} \$ 723,00$ \\
\hline Bolsa Família & $\mathrm{R} \$ 149,00$ & $\mathrm{R} \$ 1.783,00$ \\
\hline Seguro Defeso & $\mathrm{R} \$ 11,00$ & $\mathrm{R} \$ 129,00$ \\
\hline Org.: Costa e Coelho, 2018 &
\end{tabular}

Os valores presentes na Tabela 4 estão descritos por meio de valores médios (são médias por domicílios) recebidos ao mês e ao ano. As aposentadorias correspondem aos principais ingressos entre todos os benefícios à renda dos grupos domésticos. As médias de ingressos dessa fonte foram de $R \$ 420,00$ por mês e de $R \$ 5.037,00$ ao ano. O benefício Bolsa Família rende em média $R \$ 149,00$ mensais e cerca de $R \$ 1.783,00$ ao ano. O Auxílio Doença tem contribuição de $R \$ 60,00$ mensais e $R \$ 723,00$ por ano. Benefícios como Pensão e Seguro Defeso somam $R \$ 29,00$ por mês e $R \$ 353,00$ por ano, $R \$ 11,00$ mensais e $R \$ 129,00$ ao ano. 
Esses valores não são fixos, são apenas médias feitas na pesquisa para entender a realidade dos entrevistados.

\section{O PAPEL DOS BENEFÍCIOS NAS COMUNIDADES RURAIS DE TEFÉ}

O PBF, com cobertura em 11 milhões de domicílios, é um dos maiores instrumentos de política social brasileira em número de beneficiários. O Programa é superado em número de beneficiários apenas pelo Sistema Único de Saúde, que em princípio cobre toda a população brasileira; pela Educação Pública, que atende a 52 milhões de alunos; e pela Previdência Social, que ostenta 21 milhões de benefícios concedidos. (SOARES; SÁTYRO, 2009, p. 12)

Os primeiros sinais do que viria a ser o PBF (Programa Bolsa Família) surgiram em 1995 em experiências locais. Na esfera federal, o primeiro programa de transferência foi o que tinha como objetivo combater o trabalho infantil, o Programa de Erradicação do Trabalho Infantil (PETI). Focalizado em crianças expostas às ameaças do trabalho de risco, ele foi instituído em 1996, portanto, ainda no governo de Fernando Henrique Cardoso. Foi o governo do PSDB também que criou em 2001 o Bolsa Escola, inspirado no programa de Brasília. Depois dele, veio o Bolsa Alimentação e, por fim, o Cartão Alimentação, este, já no governo Lula. (THOMÉ, 2011, p. 96).

Diante disso, já no primeiro ano do governo petista, o governo federal decidiu unificar os programas criando o PBF, sendo a este incluído também o Vale Gás, programa de subsídio ao gás de cozinha (THOMÉ, 2011, p. 96). Um programa de transferência de renda do governo federal, estabelecido pela Medida Provisória 132, de 20 de outubro de 2003, transformada em lei em 2004, por meio da Lei Federal no 10.836, o PBF passou a ser de responsabilidade do Ministério do Desenvolvimento Social e Combate à fome (MDS) (THOMÉ, 2011, p. 96).

As análises apresentadas no tópico abaixo correspondem aos dados coletados por meio de entrevistas abertas com os entrevistados e traduzem as suas opiniões sobre os benefícios que recebem, bem como as observações do pesquisador em campo.

Sobre a importância dos benefícios, os entrevistados declaram que receber algum benefício "é importante", especialmente pela segurança econômica dos grupos, tendo em vista que a garantia de renda regular é também relacionada à segurança alimentar, bem como uma alternativa nos momentos de insegurança econômica, como destacado por uma das entrevistadas ao falar da importância do benefício Bolsa Família:

"Foi só melhora, porque assim, antes ninguém tinha um programa desse como o bolsa família, e pra mim assim melhorou porque não é todo ano que você tá trabalhando e nossos filhos precisam na escola, precisam pra você comprar um material, um calçado, uma roupa, pra mim foi tudo de bom e eu queria que nunca parasse, pra mim foi bom, é 
ótimo e muita gente também precisam demais, todos precisam, mais inclusive as vezes tem umas que ainda precisam ainda mais e mais, e tipo assim, agora como tá acontecendo de as pessoas serem suspensas, são pessoas que mais precisam, na minha opinião foi excelente" (ANA, 2018).

Outro ponto destacado nesta entrevista refere-se à principal contribuição dos benefícios para as famílias. A esse respeito, outra entrevistada argumenta que:

\begin{abstract}
"Os benefícios contribuem de forma significativa, de maneira que podemos comprar o material escolar dos meus filhos, que é uma contribuição, que ele ajuda né, no próprio remédio que eu compro pra eles quando eles estão doentes. Isso é uma contribuição que eu acho que o governo [dá]... e até mesmo na própria alimentação dos meus filhos, quando eu tiro o dinheiro vou comprar os alimentos pra eles, se não tiver comida, bebida, se não tiver um calçado num vai pra escola, isso tudo ele contribui, para o investimento dos meus filhos" (VICENTINA, 2018).
\end{abstract}

Nesse sentido, é perceptível que os benefícios são elementos que garantem cuidados tanto com a saúde, quanto com a alimentação dos beneficiários. Por outro lado, podemos analisar que, ao mesmo tempo que se emprega o dinheiro recebido com os benefícios, observa-se a intenção de declarar que o emprego do dinheiro dos benefícios é visto como um "investimento nos filhos", seja com saúde, alimentação ou educação, o que passa a cumprir com o papel destes, no caso do Bolsa Família.

Vemos também que a posse de algum benefício, como já apontado por Barros, Fiúza e Pinto (2017), quando analisam o impacto da renda da aposentadoria rural, cria nas famílias beneficiárias um "habitus" de seguridade social caracterizado por novas perspectivas e práticas incorporadas em suas vidas. No caso de programas de transferência de renda, como o Bolsa Família, também direcionam a este mesmo caminho, uma vez que a da renda desses benefícios é utilizada na compra de vestuários, material escolar e também para compra de itens de subsistência.

Outro ponto que analisamos foi a relação do benefício Bolsa Família ser gerido pelas mulheres. Podemos identificar que nossas entrevistadas acreditam ser a melhor forma de uma boa gestão. Segundo elas, esse fato permite que a mulher fique mais à vontade, uma vez que é ela quem consegue direcionar os rendimentos provenientes do programa para seus verdadeiros objetivos. Como podemos perceber na fala de dona Caçula: "eu me sinto mais à vontade né, porque estando no meu nome eu sei em que gasto em que não gasto. E assim tá comigo eu compro alimento, roupa, e até o gás eu compro quando acaba. Estando no meu nome eu faço tudo isso".

Ao mesmo tempo, alguns dos nossos entrevistados, como o senhor André, declara que: "se o cartão fosse no meu nome, eu também usaria para comprar as coisas das crianças e para ajudar a nossa casa". Sobre o cartão vir em nome (preferencialmente) das mulheres, 
Rego e Pinzani (2013) destacam que tal processo gera maior autonomia, nesse caso, às mulheres.

Outra questão que buscamos entender se insere nos possíveis pontos positivos e negativos do benefício Bolsa Família. Os entrevistados declaram que os efeitos são sempre positivos, especialmente por terem que cumprir as condicionalidades do benefício para garantir a renda. Sobre isso, o senhor João Sabiá (2018) destaca:

"O bolsa família trouxe, trouxe um efeito positivo, porque em primeiro lugar, é a ajuda
que a gente tem que é o dinheiro, em segundo lugar é que eu não deixo meus filhos
faltarem tanto na escola por causa do bolsa família, não deixo faltar ou atrasar as
vacinas por causa do bolsa família, então antes disso tudo era atrasado, aí hoje a gente
tem que ter um maior cuidado com isso, escola, vacina por causa do bolsa família, então
esse foi o efeito bom que ele trouxe para minha vida e também o alimento que a gente
compra" (JOÃO SABIÁ, 2018).

Assim, destacamos que o impacto do benefício Bolsa Família nos domicílios é evidente e demonstra que atinge seus objetivos, que é condicionar a renda e garantir a frequência escolar e a manutenção dos serviços básicos de saúde dos filhos.

Quando indagamos os entrevistados sobre os benefícios serem um direito ou favor que o Estado faz às famílias, podemos perceber que todos declaram que são direitos que devem "ser garantidos às famílias que precisam", tanto o Bolsa Família, como as aposentadorias, auxílios e pensões, já que cumprem os requisitos necessários para terem acesso a eles. A senhora Holanda argumenta que:

"Eu acho que é um direito nosso, não só meu, como de todas as famílias que precisam. É UM DIREITO DAS FAMILIAS, porque nós pagamos impostos da gasolina, ao quilo de açúcar, do café, de tudo a gente contribui com imposto, então eu acho assim que desse imposto deve sobrar muito dinheiro que pode ser financiado em programas sociais, inclusive como o do bolsa família", seguro defeso, auxilio maternidade e auxilio doença (HOLANDA, 2018).

Um dos principais elementos identificados neste estudo refere-se às mudanças que os entrevistados percebem a partir do recebimento de algum benefício social. Pode-se fazer uma relação dessas mudanças e suas orientações econômicas, o que Lima e Peralta (2016) destacam sobre a penosidade do trabalho e a relação com a orientação econômica e satisfação das necessidades de consumo dos grupos familiares. A senhora Maria dos Prazeres relata que:

"No dia de receber né, aí eu vou sacar o dinheiro, porque assim eu tiro umas férias sobre o trabalho da agricultura né, aí eu passo uns, dois dias ou três dias em casa, pensando né o que que eu vou fazer? digo, já tô cansada de ir pra roça né, vou parar uns dois dias ou três dias..., porque de primeiro, todo os dia, todo os dia pra agricultura, pra roça, pra roça aí eu me sentia cansada, eu digo, hoje eu não vou porque recebi o bolsa família, tenho que ficar um pouco em casa, tomando conta da casa, fazendo o que eu preciso na minha casa, aí cuidando, dando mais atenção pros meus meninos em casa, teve um bocado de mudança... a gente tem muita coisa pra citar, mais o necessário que eu me sinto é nesse ponto aí, que eu paro mais em casa, eu me sinto como diz mais despreocupada..."(MARIA DOS PRAZERES, 2018). 
Podemos perceber que, nesse sentido, os benefícios garantem, de certa forma, uma condição de segurança das famílias, uma vez que a obrigatoriedade de "ir à roça" pode ser descumprida em algum momento (mesmo que em período curto) pois há uma segurança, possibilitada pelo recebimento do benefício social. Isso também foi identificado em domicílios que têm acesso às aposentadorias, como na família da senhora Maria Dos Prazeres, 2018. Nessas famílias, tal cenário se faz mais evidente, talvez pelo rendimento ser mais elevado em relação ao Bolsa Família.

Por fim, tentamos identificar como é usado o dinheiro dos benefícios. Identificamos que - Bolsa Família é mais empregado na compra de vestuário, material para os filhos, alimentação. As aposentadorias são destinadas também às compras dos itens mencionados, mas, em casos mais específicos, são investidas em remédios, exames, viagens para tratamento de saúde e em compra de bens de patrimônio. Como destaca dona Maria Dos Prazeres:

\begin{abstract}
"Nós usamos o dinheiro, no gás, no peixe, no frango, açúcar, café, muitas das vezes a gente num faz farinha, que demora pra fazer, até a farinha mesmo a gente agricultor as vezes se atrasa pra fazer, aí tem que comprar uns litros até aprontar, e até torrar nossa farinha, é comprando umas roupas, caçados, principalmente quando estão estudando já, uma mochila pra um outra mochila pra outro, ai um kit completo sobre a escola, borracha, caderno, lápis, cola tudo né, então ai tudo é usado esse dinheiro bolsa família, a conta de energia, mais tudo é pelo bolsa família, a gente usa comprando todas as coisas com o bolsa, e ainda sobra um pouquinho, porque vou tirando de pouquinho o que der pra comprar eu vou comprando, então é usado praticamente em todas as coisa, o sal, fosforo, é vamos dizer até se os meninos quiserem tomar um refrigerante, uma bolacha, salgado o pão da manhã pro café, arroz, macarrão o que der pra comprar com o bolsa a gente compra, é isso, comprar um monte de coisa com o bolsa, eu agradeço muito a Deus, por ter chegado esse bolsa família (MARIA DOS PRAZERES, 2018).
\end{abstract}

Destacamos ainda que possuir um cartão de benefício como o Bolsa Família e a aposentadoria, por exemplo, é uma garantia de crédito no mercado, pois como são rendimentos mensais regulares, garantem poder de compra aos beneficiários. Assim, cabe destacar que, de forma direta, os benefícios sociais como o Bolsa Família e a aposentadoria são os principais benefícios que contribuem para a composição da renda dos domicílios analisados. Esses elementos possibilitam novos cenários na economia dos trabalhadores e moradores das comunidades das estradas da Agrovila e Emade, no município de Tefé.

\title{
CONSIDERAÇÕES FINAIS
}

De acordo com os resultados apresentados no decorrer deste estudo, observou-se que a aposentadoria é o benefício social de maior impacto monetário na composição de renda dos domicílios. O Bolsa Família é o segundo que mais contribui para renda e assume importância 
cada vez maior no meio rural, na cidade de Tefé, tanto para os beneficiários como para suas famílias e para a economia do município onde residem.

Foi possível constatar que os benefícios sociais têm grande importância no meio econômico das comunidades rurais na cidade de Tefé e também influenciam na economia do município. Notou-se, ainda, que o maior ou menor grau de dependência desses recursos por parte das famílias rurais está relacionado com as características da agricultura familiar local ou com a orientação econômica dos grupos familiares, fato que reflete no peso das aposentadorias e/ou pensões e bolsas na composição da renda total dos domicílios em relação a outras fontes de ingressos monetários.

Se pensarmos do ponto de vista da orientação econômica dos grupos familiares, estes tendem a diminuir o esforço dedicado ao trabalho se atingem as necessidades de consumo, como dizem os mesmos, "dão uma parada no trabalho" e não precisam se esforçar ao máximo, por terem atingido o seu objetivo em relação a sua subsistência ou compra de um bem material.

Assim, podemos estar diante de uma possível mudança, especialmente nas relações de trabalho, como podemos analisar naqueles domicílios que possuem algum benefício social. Esse novo "habitus" se apresenta no pequeno ato de famílias que "tiram folga" do trabalho, bem como por domicílios que podem ter acesso a itens de consumo que antes não era possível de adquirir, como fogão a gás, telefone celular e máquina de lavar roupas.

Desse modo, cabe destacar que, os benefícios sociais como Bolsa Família e aposentadorias, pensões e outros são os principais que contribuem de forma direta na economia dos trabalhadores e moradores das comunidades rurais. Seu papel talvez seja, pelos dados apresentados, de elementos estruturadores das relações de manutenção da subsistência dos grupos analisados. Isso pode ficar evidente quando analisamos os dados sobre o emprego/uso dos benefícios que na maioria das vezes são destinados à aquisição de itens provenientes do mercado, como roupas, remédios, rancho, tratamento de saúde, bens de patrimônio, entre outros, artigos que não são produzidos pelo próprio grupo, mas que são necessários à manutenção e bem-estar das famílias.

Assim, o cenário de carência de políticas públicas específicas para famílias rurais contribui para geração de problemas e ampliação das desigualdades sociais no meio rural. Neste cenário, o acesso aos recursos oriundos de benefícios sociais apresenta-se como uma contribuição significativa para a manutenção e ampliação da renda dos domicílios familiares e, ao mesmo tempo, a garantia de uma segurança social e econômica dos grupos analisados neste estudo. 


\section{REFERÊNCIAS}

ABRAMOVAY, RICARDO. Paradigmas do capitalismo agrário em questão. 2 ed. São Paulo. Hucitec, 1998.

BARROS, Vanessa Aparecida Moreira de; FIÚZA, Ana Louise de Carvalho; PINTO, Neide Maria de Almeida. Habitus da previdência social no estilo de vida das famílias rurais: o caso dos municípios de São Miguel do Anta e Piranga/ Habitus da seguridade social no estilo de vida das famílias rurais: o caso da São Municípios Miguel do Anta e Piranga na Zona da Mata Mineira, Brasil. Ciência Rural, Santa Maria, v.47, n.6, 2017.v. http://dx.doi.org/10.1590/01038478 cr20151191.

COELHO, Alex Almeida; PERALTA, Nelissa. Retrato histórico da economia domiciliar em comunidades de várzea na região de Fonte Boa, Alto Solimões. In: 11 Simpósio sobre Conservação e Manejo Participativo na Amazônia, 2014, Tefé - AM.

COELHO, ALEX ALMEIDA; PERALTA, NELISSA. "Meu patrão é meu dinheiro": mudanças nas relações comerciais de pequenos produtores rurais do médio Solimões (AM), 2010. Revista de Economia Política e História Econômica, número 35, janeiro de 2016.

FERREIRA, Carlos Roberto; SOUZA, Solange de Cássia Inforzato de. As aposentadorias e pensões e a concentração dos rendimentos domiciliares per capita no Brasil e na sua área rural: 1981 a 2003. RER, Rio de Janeiro, vol. 45, № 04, p. 985-1011, out/dez 2007.

THOMAZ JUNIOR, Antônio. Capital, Trabalho, Território e Sustentabilidade: a Geografia Agrária nas contradições do desenvolvimento brasileiro. Campo-Território: revista de geografia agrária. Edição especial do XXI ENGA-2012, p. 1-15, jun., 2014.

LIMA, Deborah de Magalhães. A economia doméstica em Mamirauá In: ADAMS, Cristina; MURRIETA, Rui; NEVES, Walter (orgs) Sociedades Caboclas Amazônicas: modernidade e invisibilidade. São Paulo: Annablume, 2006.

LIMA, Deborah Magalhães. A economia doméstica em Mamirauá. In: ADAMS, Cristina; MURRIETA, Rui; e NEVES, Walter (orgs.). Sociedades caboclas amazônicas: modernidade e invisibilidade. São Paulo Annablume, 2006, p. 145-172.INDO, Paula Vanessa de Faria. Geografia e política de assistência social: territórios, escalas e representações cartográficas para políticas públicas. São Paulo: Cultura acadêmica, 2011.

OLIVEIRA, ARIOVALDO UMBELINO. Modo de Produção Capitalista, Agricultura e Reforma Agrária. São Paulo: FFLCH, 2007, 184p.

PERALTA, N.; LIMA, D. M. A Comprehensive overview of the domestic economy in Mamirauá and Amanã in 2010. UAKARI, v. 9, n. 2 , p. 33 - 62, 2013.

PERALTA, NELISSA. "Toda Ação de Conservação Precisa ser Aceita pela Sociedade" Manejo Participativo em Reserva de Desenvolvimento Sustentável. Tese de Doutorado em Sociologia - Faculdade de Filosofia e Ciências Humanas da Universidade Federal de Minas Gerais. Belo Horizonte, MG: UFMG, 2012. 325p. 
POCHMANN, MARCIO. Estrutura social no Brasil: mudanças recentes. Serv. Soc. Soc., São Paulo, n. 104, p. 637-649, out./dez. 2010.

PRAZERES, MARIA DOS. Entrevista concedida no dia 07-09-2018. Comunidade de Maranata.

REGO, WALQUIRIA LEÃO; PINZANI, ALESSANDRO. "Vozes do Bolsa Família: autonomia, dinheiro e cidadania". - São Paulo: Editora Unesp, 2013.

ROGERSON, Peter A. Métodos estatísticos para geografia: um guia para o estudante. Tradução técnica: Paulo Fernando Brag, José Irineu Rangel Rigotti. - 3. Ed. - Porto Alegre : Bookman Editora, 2012.

RUFINO, CAÇULA. Entrevista concedida no dia 06-09-2018. Comunidade de Agrovila.

SCHNEIDER, SERGIO; BIOLCHI, MARILZA. A previdência social e seus impactos sociais e econômicos no meio rural do Rio Grande do Sul. Revista Indicadores Econômicos FEE, Porto Alegre, v. 30, n. 4, p. 27-42, 2003.

SCHWARZER, Helmut; QUERINO, Ana Carolina. Benefícios Sociais e Pobreza: Programas Não Contributivos Da Seguridade Social Brasileira. TEXTO PARA DISCUSSÃO № 929. Governo Federal Ministério do Planejamento, Orçamento e Gestão, Ipea (Instituto De Pesquisa Econômica Aplicada) Brasília, dezembro de 2002.

SILVA, Jorge Luiz Mariano da; LOPES, Tatiana de Santana. Efeitos da Previdência Social Sobrea Desigualdade e a Pobreza Rural no Nordeste: Uma Análise da Decomposição do Índice de Gini. REN, Volume 40 № 01, janeiro - Março 2009. Disponível em: https://ren.emnuvens.com.br/ren/article/view/347/297.

SOARES, Sergei; SÁTYRO, Natália. O Programa Bolsa Família: Desenho Institucional, Impactos e Possibilidades Futuras. Texto para Discussão No. 1424. Instituto de Pesquisa Econômica Aplicada (IPEA). Brasília, 2009.

THOMÉ, Débora. O Programa Bolsa Família e a Social-Democracia: uma análise institucional. Revista Brasileira de Monitoramento e Avaliação. Brasília, DF: Ministério do Desenvolvimento Social e Combate à Fome; Secretaria de Avaliação e Gestão da Informação, 2011.

VIANA, Virgílio. Bolsa Floresta: um instrumento inovador para a promoção da saúde em comunidades tradicionais na Amazônia. Estudos Avançados, São Paulo, v. 22, n. 64, 2008.

WEISSHEIMER, Marco Aurélio. Bolsa família: avanços, limites e possibilidades do programa que está transformando a vida de milhões de famílias no Brasil. - São Paulo: Editora Fundação Perseu Abramo, 2006. 